\title{
EFEKTIVITAS PELATIHAN SHALAT KHUSYUK DALAM MENURUNKAN KECEMASAN PADA LANSIA HIPERTENSI
}

\section{THE EFFECTIVENESS OF TRAINING SOLEMN PRAYER TO REDUCE ANXIETY IN THE ELDERLY HYPERTENSION}

\author{
Yulia Wardani \\ H. Fuad Nashori \\ Qurotul Uyun \\ Fakultas Psikologi dan Ilmu Sosial Budaya Universitas Islam Indonesia Yogyakarta \\ Email: yuliawardhanie16@gmail.com
}

\begin{abstract}
This study aimed to examine the effect of Solemn Prayer training to reduce anxiety in the elderly with hypertension and can provide peace of mind. Subjects in this study amounted to 9 elderly, who were divided into 5 experimental groups and 4 control groups. Measuring instruments used in this research is scale BAI (Beck Anxiety Scale) were given at the pre-test, post-test and follow-up. Analysis of the research is quantitative analysis using Anova Repeated Parametric Measurement to determine the level of anxiety of elderly hypertensive after the training given solemn prayer. The result of research indicates that effective fervent prayer training to reduce anxiety elderly hypertension with $F=75.075$ and $p=0.00(p<0.05)$. This study shows that training solemn prayer can be used as one way to reduce anxiety in elderly hypertensive.
\end{abstract}

Keywords: Anxiety, Training Solemn Prayer, Elderly Hypertension

\begin{abstract}
ABSTRAK
Penelitian ini bertujuan untuk mengetahui pengaruh pelatihan shalat khusyuk untuk menurunkan kecemasan pada lansia hipertensi. Subjek dalam penelitian ini berjumlah 9 lansia, dengan perincian 5 orang masuk kelompok eksperimen dan 4 orang masuk kelompok kontrol. Alat ukur yang digunakan dalam penelitian ini adalah skala BAI (Beck Anxiety Scale) yang diberikan pada saat prates, pascates dan tindak lanjut. Analisis penelitian yang digunakan adalah analisis kuantitatif parametrik menggunakan Anava Repeated Measurement untuk mengetahui tingkat kecemasan lansia hipertensi setelah diberi pelatihan shalat khusyuk. Hasil penelitian menunjukkan bahwa pelatihan shalat khusyuk efektif menurunkan kecemasan lansia hipertensi dengan $F=75,075$ dan $p=0,00(p<0,05)$. Penelitian ini menunjukkan bahwa pelatihan shalat khusyuk dapat digunakan sebagai salah satu cara untuk menurunkan kecemasan pada lansia hipertensi.
\end{abstract}

Kata kunci : Kecemasan, Pelatihan Shalat Khusyuk, Lansia Hipertensi 
Hipertensi adalah kondisi medis yang terjadi akibat peningkatan tekanan darah secara kronis (dalam jangka waktu lama). Klasifikasi tekanan darah tinggi biasanya terjadi saat mencapai 140/90 mmhg (Dinkes, 2013). Salah satu tipe hipertensi tinggi adalah hipertensi esensial (essential hypertension). Pada gangguan ini, munculnya hipertensi tinggi pada seseorang tidak disertai dengan adanya penyebab fisik yang pasti. Oleh karena itu diduga penyakit tersebut muncul karena faktor psikologis. Berbagai kondisi atau peristiwa yang menekan diyakini dapat menyebabkan meningkatnya hipertensi (walaupun hanya sementara).

Hipertensi dan penyakit kardiovaskular lainnya, sebagaimana dilaporkan beberapa rumah sakit di Daerah Istimewa Yogyakarta, merupakan penyebab kematian tertinggi (Dinkes DIY, 2013). Hasil riset kesehatan dasar tahun 2013 menempatkan Daerah Istimewa Yogyakarta sebagai urutan ketiga jumlah kasus hipertensi di Indonesia berdasarkan diagnosis atau riwayat minum obat. Hal ini mengalami kenaikan jika dibandingkan dari hasil riset kesehatan dasar pada tahun 2007.

Daerah Istimewa Yogyakarta menempati urutan kesepuluh dalam jumlah kasus hipertensi berdasarkan diagnosis atau riwayat minum obat (Kemenkes RI, 2013). Hipertensi dapat disebabkan oleh beberapa faktor, di antaranya yaitu faktor genetik, obesitas, kecemasan yang menimbulkan stres, konsumsi garam berlebih, makanan berkolesterol, merokok, alkohol dan hormon (Kabo, 2010). Dari penjelasan terungkap bahwa salah satu penyebab lansia menderita hipertensi adalah kecemasan yang menimbulkan stres.

Peningkatan jumlah lanjut usia membutuhkan penanganan yang serius karena secara alamiah lanjut usia itu mengalami penurunan fungsi, baik fisik, biologis, maupun mentalnya. Hal ini tidak terlepas dari masalah ekonomi, sosial, dan budaya sehingga perlu adanya peran keluarga dan peran sosial dalam penanganannya. Menurunnya fungsi berbagai organ lansia menjadi rentan terhadap penyakit yang bersifat akut atau kronis. Ada kecenderungan terjadi penyakit degeneratif, penyakit metabolik, gangguan psikososial, dan penyakit infeksi meningkat (Nugroho, 2004).

Kelompok rentan yang mempunyai kemungkinan terbesar untuk menjadi korban perubahan sosial adalah kelompok usia lanjut. Umumnya mereka memiliki konsep hidup tradisional, seperti harapan akan dihormati dan dirawat di masa tua, atau hubungan erat dengan 
anak yang telah dewasa. Pada kenyataannya mereka harus hidup dalam sistem nilai yang berbeda dengan yang dianut, misalnya kurang perasaan dihormati, karena anak tidak lagi tergantung secara ekonomi pada orang tua, serta kurangnya waktu bagi menantu perempuan untuk menjaga orang tua, karena bekerja. Keadaan ini dapat memengaruhi psikologis dan kesejahteraan lanjut usia (Isfandari, 1999).

Gangguan kecemasan atau gejala kecemasan yang mengarah kepada gangguan kecemasan pada lansia memiliki dampak negatif bagi kehidupan mereka. Menurut Brens, Guralnik, Williamson, Frierd, dan Pennix (Ayers, Sorrell, Throp, \& Wetherell, 2007), dampak yang dapat ditimbulkan akibat simtom atau gejala cemas pada lansia ialah keluhan mengenai kondisi fisik lansia, misalnya meningkatnya ketidakmampuan secara fisik dan kepuasan hidup lansia. Beck (1989) mengungkapkan bahwa kecemasan terjadi karena adanya penilaian kognitif yang tidak tepat terhadap sumber kekhawatiran atau stressor. Jika individu mampu memberikan penilaian kognitif secara tepat, maka kecemasan tidak terjadi.

Menurut Papalia, Olds, dan Feldman (2008), upaya mengatasi kecemasan yang dialami lansia dapat dilakukan melalui kajian ulang kehidupan, olahraga, religiositas dan dukungan sosial. Pandanganan yang disampaikan Nashori (2007) menyatakan bahwa religiositas membuat individu mengurangi afek-afek negatif, seperti stres, cemas, gelisah, dan putus asa. Religiositas diyakini mampu mem-berikan kekuatan bagi manusia dalam kehidupannya agar lebih tenang dalam menghadapi kehidupan yang semakin kompleks. Pernyataan Nashori di atas didukung oleh hasil penelitian Irawati, Subandi, dan Kumolohadi (2011) bahwa pelatihan kognitif religius untuk menurunkan kecemasan.

Peneliti ingin melakukan penelitian dan sesuai dengan saran yang diberikan oleh Irawati, Subandi, dan Kumolohadi (2011) bahwa intervensi akan maksimal jika diaplikasikan dalam kegiatan seharihari. Peneliti tertarik untuk melakukan penelitian dengan memberikan intervensi religius yang dapat dilakukan setiap hari, misalnya subjek melakukan ibadah sholat yang dapat memberikan ketenangan hati. Intervensi religius yang diberikan bermanfaat jika dilakukan oleh subjek penelitian setiap hari.

Menurut Najati (2005), kehidupan religius atau keagamaan dapat membantu manusia dalam menurunkan kecemasan, kegelisahan, dan ketegangan. Salah satu peran religiositas adalah meningkatkan 
ketenangan qalbu. Hal ini terdapat dalam surat $\mathrm{Ar}-\mathrm{Ra}^{\prime} \mathrm{du}$ ayat 28 yang berbunyi: "(yaitu) orang-orang yang beriman dan hati mereka menjadi tenteram dengan mengingat Allah. Ingatlah, hanya dengan mengingati Allah-lah hati menjadi tenteram." Imam Ibnu Rajab al-Hambali berkata: "Sungguh Allah telah mensyariatkan bagi hamba-hamba-Nya berbagai macam ibadah yang akan tampak padanya kekhusyukan (anggota) badan (seorang hamba) yang bersumber dari kekhusyukan, ketundukan dan kerendahan diri dalam hatinya. Ibadah yang paling tampak padanya kekhusyukan adalah ibadah shalat. Allah Ta'ala memuji hambahamba-Nya yang khusyuk dalam shalat mereka dalam firman-Nya: "Sesungguhnya beruntunglah orang-orang yang beriman, (yaitu) orang-orang yang khusyuk dalam shalatnya" (QS al-Mu'minuun: 12).

Selain itu, ada hadits yang membahas tentang shalat khusyuk. Orang yang sedang shalat lalu hendak dimangsa hewan yang beracun, maka dia boleh membunuhnya, tanpa kehilangan kekhusyukan shalatnya. Sesuai dengan Hadits yang diriwayatkan oleh Aisyah R.A istri Rasulullah SAW berkata bahwa Rasullullah SAW sedang shalat di rumah, datanglah Ali bin Abi Thalib. Ketika melihat Rasulullah SAW sedang shalat, maka Ali pun ikut shalat di sebelah beliau. Lalu datanglah kalajengking hingga berhenti di dekat Rasulullah SAW namun meninggalkannya dan menghadap ke Ali. Ketika Ali melihat kalajengking itu, Ali pun menginjaknya dengan sandalnya. Dan Rasulullah SAW memandang tidak mengapa pembunuhan itu terjadi dalam shalat (HR. Al-Baihaqi dan Ath-Thabarani).

Selain itu, menurut Ancok dan Suroso (2011), shalat dapat mengurangi bahkan menghilangkan kecemasan yang ada dalam diri seseorang. Ancok dan Suroso menjelaskan bahwa ada empat aspek terapeutik di dalam shalat terutama shalat khusyuk, antara lain aspek olah raga, aspek meditasi, aspek auto-sugesti, dan aspek kebersamaan. Aspek olah raga dalam shalat tampak pada aktivitas fisik, seperti kontraksi otot, tekanan, dan massage pada bagian otot tertentu yang dapat menimbulkan proses relaksasi, sehingga dapat mengurangi kecemasan.

Shalat khusyuk juga memiliki aspek meditasi. Asumsinya shalat khusyuk dapat menghadirkan hati untuk dapat bermunajat (berbincang-bincang) dengan Tuhan sehingga membutuhkan konsentrasi. Dalam aspek meditasi ini akan muncul rasa kekhusyukan yang dapat menghilangkan kecemasan karena merangsang sistem syaraf lain yang akan 
menutup terbawanya rangsangan sakit tersebut ke otak (Ancok \& Suroso, 2011).

Aspek auto-sugesti shalat terletak pada sugesti dari doa-doa dan pujianpujian dalam shalat. Pujian-pujian bertujuan untuk memohon sesuatu yang bermakna dan berdampak baik pada diri. Aspek inilah yang memberikan sugesti terhadap diri untuk berbuat baik (Ancok \& Suroso, 2011).

Selanjutnya, aspek kebersamaan didapatkan dalam shalat berjamaah dapat dikembangkan menjadi pelatihan kelompok. Asumsi yang dibangun adalah suasana kebersamaan membebaskan orang dari perasaan keterasingan yang menjadi penyebab gangguan jiwa (Ancok \& Suroso, 2011).

Senada dengan pandangan di atas, Syed (2003) berpandangan bahwa shalat menyebabkan kebahagiaan dan kegembiraan dalam pikiran, mengurangi kecemasan, dan memadamkan api kemarahan. Nashori (1997) mengungkapkan sholat menghasilkan ketenangan, konsentrasi yang terarah, dan kebijaksanaan. Sharp (2010) melakukan penelitian yang menunjukkan bahwa orang yang berhubungan dengan Tuhan melalui doa akan membantu mengatur emosi negatif.

Berdasarkan penelitian yang dilakukan oleh Adi (2002) diketahui bahwa shalat memiliki kemampuan untuk mengurangi kecemasan. Shalat merupakan bagian dari praktek keagamaan yang digunakan sebagai sarana beribadah kepada Allah. Shalat memiliki peranan yang penting untuk kesehatan psikologis seseorang. Sebagaimana yang dikemukakan oleh Ashy (1999), shalat lima waktu membantu mengurangi tekanan psikologis, memelihara keteraturan dan kedisiplinan dalam kehidupan seseorang.

Uyun dan Rumiani (2012) mengatakan bahwa shalat dalam Islam merupakan doa dan gerakan-gerakannya merupakan gerakan yang harus dilakukan dengan khusyuk penuh dengan ketundukan hati, sehingga akan berefek menenangkan (relaksasi). Orang yang mampu melakukan shalat dengan khusyuk akan merasakan ketenangan jiwa.

Dengan mendapatkan pelatihan shalat khusyuk, pasien lansia hipertensi akan mendapatkan manfaat, yaitu melapangkan dada, membuat jiwa bahagia, menjauhkan penyakit dari tubuh, membuat jiwa dan raga aktif, mendapatkan asupan gizi bagi ruh dan hati. Selain itu, shalat dengan khusyuk merupakan sarana paling utama untuk mendekatkan diri kepada Allah SWT (Ahmad, 2008). Berdasarkan penjelasan tersebut, peneliti bermaksud melakukan penelitian eksperimen. Peneliti ingin membantu mereka dalam menurunkan tingkat kecemasan 
pada pasien lansia hipertensi. Para pasien lansia diajarkan dan diberi pelatihan shalat khusyuk agar benar-benar dapat memberikan dampak bagi pasien yaitu ketenangan hati.

Peneliti bermaksud menguji pengaruh salah satu aktivitas utama religiositas, dalam hal ini adalah shalat khusyuk, terhadap penurunan tingkat kecemasan pada pasien lansia hipertensi. Para pasien lansia diajarkan dan diberi pelatihan shalat khusyuk agar benar-benar dapat memberikan dampak bagi pasien, yaitu ketenangan hati. Dengan mendapatkan pelatihan shalat khusyuk, pasien lansia hipertensi akan mendapatkan manfaat, yaitu melapangkan dada, membuat jiwa bahagia, menjauhkan penyakit dari tubuh, shalat membuat jiwa dan raga aktif, mendapatkan asupan gizi bagi ruh dan hati. Selain itu, shalat dengan khusyuk merupakan sarana paling utama untuk mendekatkan diri kepada Allah SWT (Ahmad, 2008).

Dengan penjelasan di atas, peneliti mengajukan hipotesis bahwa ada penurunan kecemasan setelah lansia mengikuti pelatihan shalat khusyuk.

\section{METODE PENELITIAN}

\section{Desain Penelitian}

Penelitian ini dilakukan dengan kuasi eksperimen dengan menggunakan desain non randomized pretest-posttest control design, yaitu desain eksperimen yang dilakukan dengan prates dan pascates yang melibatkan kelompok eksperimen dan kelompok kontrol. Subjek penelitian dibedakan antara kelompok eksperimen dan kelompok kontrol yang ditentukan dengan cara non random (Seniati,Yulianto \& Setiadi, 2005).

Tabel 1. Desain Penelitian

\begin{tabular}{ccccc}
\hline Kelompok & Prates & Perlakuan & Pascates & Tindak lanjut \\
\hline Eksperimen & O1 & $\mathrm{X}$ & $\mathrm{O} 2$ & O3 \\
Kontrol & $\mathrm{O} 1$ & $\sim \mathrm{X}$ & $\mathrm{O} 2$ & $\mathrm{O} 3$ \\
\hline
\end{tabular}

Keterangan :

KE : Kelompok eksperimen

O3 : Tindak lanjut

KK : Kelompok kontrol

$\mathrm{X} \quad$ : Perlakuan

O1 : Pengukuran prates

-X : Tanpa perlakuan

O2 : Pengukuran pascates 


\section{Subjek Penelitian}

Subjek penelitian adalah lansia hipertensi dengan kriteria sebagai berikut: (1) Lansia (berusia 60 tahun ke atas) yang mengalami kecemasan dan hipertensi. (2) Beragama Islam. (3) Memiliki kriteria kecemasan tinggi atau sedang. (4) Bersedia secara sukarela mengikuti pelatihan.

\section{Metode Pengambilan Data}

Pada setiap pertemuan, peserta pelatihan diukur dan dirating kecemasan, tekanan darah, serta denyut jantungnya. Kecemasan diukur dengan skala Beck Anxiety Inventory (BAI). BAl yang digunakan adalah yang dikembangkan oleh Aaron Beck pada tahun 1988, terdiri atas 21 aitem. Aitem-aitem tersebut adalah aitem-aitem yang mengungkap aspek emosi, kognitif dan fisik. Masingmasing aitem mempunyai 4 kemungkinan jawab-an di antara 0-3.

\section{Prosedur Intervensi}

Shalat khusyuk adalah shalat yang dilakukan dengan melibatkan hati, pikiran, dan gerakan dalam sebuah aktivitas shalat untuk tunduk, merendah, dan menyerahkan sepenuhnya kepada Allah. Pelatihan shalat khusyuk adalah upaya pengajaran, penyadaran dan praktik (latihan shalat khusyuk) kepada pasien lansia hipertensi untuk mendapatkan ketenangan hati sehingga tingkat kecemasannya menurun. Pelatihan shalat khusyuk ini perlu adanya usaha dalam menenangkan diri dengan cara memberikan perintah kepada pikiran, perasaan anggota tubuh agar tenang.

Subjek diberikan pelatihan shalat khusyuk. Pelatihan shalat khusyuk meliputi (1) Latihan relaksasi dengan terapi air (hydro therapy) ketika berwudhu'. (2) Latihan relaksasi dan olah kejiwaan di dalam gerakan raka'at dan bacaan shalat. (3) Latihan dzikir dan doa. Pelatihan shalat khusyuk terdiri atas 3 kali pertemuan, masing-masing pertemuan terdiri atas 4 dan 5 sesi dengan rentang waktu 100-150 menit. Total waktu adalah 370 menit.

\section{Teknik Analisis Data}

Analisis data dalam penelitian ini menggunakan BAI (Beck Anxiety Inventory) yang masing-masing diberikan saat prates pelatihan, segera setelah pelatihan, dan dua pekan setelah pelatihan. Proses penilaian dan pengukuran tersebut dilakukan untuk mengetahui apakah pelatihan shalat khusyuk yang telah dilakukan mampu membantu menurunkan kecemasan pada pasien lansia hipertensi. Proses analisis ini menggunakan perangkat lunak Statistical Product and Service 
Solution (SPSS) for Window versi 17.0.

Teknik analisis yang digunakan adalah Anava Repeated Measurement. Analisis ini juga dileng- kapi berdasarkan hasil observasi, wawan-cara, lembar kerja, dan lembar evaluasi.

\section{HASIL PENELITIAN}

\section{Deskripsi Data Penelitian}

Perbandingan skor prates dan pascates pada masing-masing kelompok dapat dilihat pada grafik berikut. Grafik perbandingan skor kecemasan masingmasing subjek di kelompok eksperimen selengkapnya dapat dilihat pada deskripsi dan pembahasan hasil penelitian persubjek.

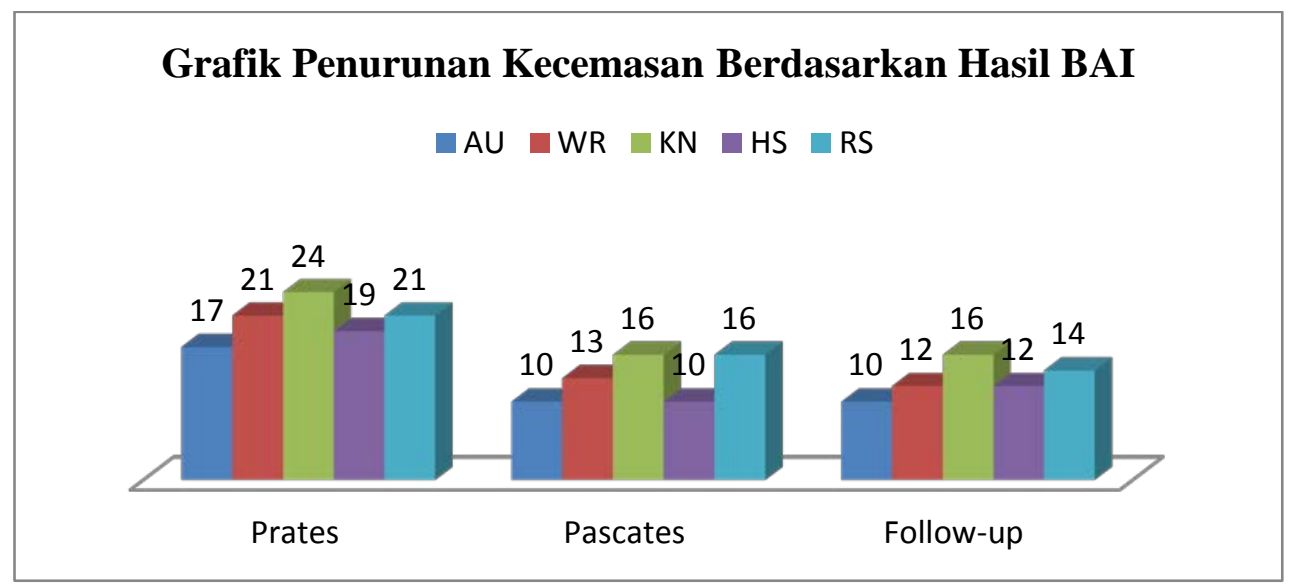

Gambar 1. Grafik penurunan kecemasan pada prates, pascates dan tindak lanjut kelompok eksperimen 


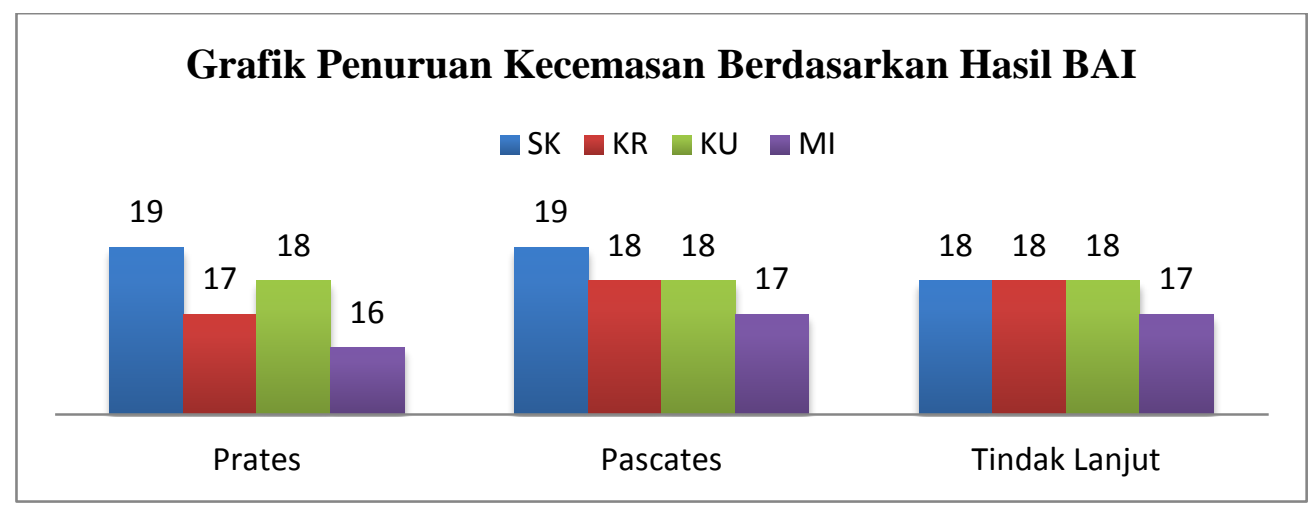

Gambar 2. Grafik Penurunan kecemasan pada prates, pascates dan tindak lanjut kelompok kelompok kontrol

Pada kelompok eksperimen terjadi perubahan rerata skor tingkat kecemasan, yaitu dari 17 pada saat prates menjadi 10 pada saat pascates. Skor rerata prates (17) dalam kategorisasi skala kecemasan termasuk dalam kategori sedang. Skor rerata pascates (10) termasuk dalam kategori kecemasan rendah. Pada kelompok kontrol tidak terjadi perubahan rerata skor tingkat kecemasan dengan jumlah skor 19. Skor rerata prates dan pascates (19) termasuk dalam kategori sedang.

Setelah proses pelatihan dilakukan, kelompok eksperimen diberi pengukuran lanjutan untuk melihat sejauh mana subjek pada kelompok tersebut menerapkan materi dan kegiatan yang telah dilatihkan dalam kehidupan sehari-hari setelah pelatihan berakhir. Skor prates, pascates, dan tindak lanjut pada kelompok eksperimen mengalami penurunan hingga masa tindak lanjut berakhir. Hal ini terlihat dari grafik, rerata skor kecemasan bergerak turun dari 17 menjadi 10. Sementara pengukuran lanjutan yang dilakukan pada kelompok kontrol ada sedikit mengalami penurunan skor dari 19 menjadi 18 .

\section{Hasil Uji Asumsi}

Uji asumsi dilakukan dengan menggunakan uji normalitas dan uji homogenitas. Pertama: Uji normalitas. Uji normalitas dilakukan dengan bantuan SPSS 17 for windows dengan menggunakan teknik one sample kolmogorovsmirnov test. Kaidah uji yang digunakan, jika $p>0,05$ maka sebaran datanya normal, jika $p<0,05$ maka sebaran datanya tidak normal. 
Tabel 2. Hasil Uji Normalitas

\begin{tabular}{llll}
\hline Perlakuan & Statistik & P & Keterangan \\
\hline Prates Eksperimen- & 0,184 & 0,20 & Normal \\
Prates Kontrol & & & \\
\hline
\end{tabular}

Berdasarkan hasil uji normalitas, Kedua: Hasil uji homogenitas. Uji peneliti mendapatkan hasil bahwa se- homogenitas dilakukan dengan bantuan baran data ini normal ( $p=0,20$ atau SPSS 17 for windows. $p>0,05)$.

Tabel 3. Uji Homogenitas

\begin{tabular}{llll}
\hline Perlakuan & Levene Statistic & $\mathrm{P}$ & Keterangan \\
\hline $\begin{array}{l}\text { Prates Eksperimen- } \\
\text { Prates Kontrol }\end{array}$ & 1,348 & 0,284 & Homogen \\
\hline
\end{tabular}

Berdasarkan hasil uji homogenitas, maka diperoleh bahwa data kedua kelompok homogen. $(p=0,284$ atau $p>0,05)$.

\begin{abstract}
Hasil Uji Hipotesis
Berdasarkan uji asumsi, syarat untuk melakukan uji hipotesis secara parametrik terpenuhi. Oleh karena itu, uji hipotesis dilakukan dengan metode parametrik, yaitu Anava Repeated Measurement.
\end{abstract}

Tabel 4. Hasil Anava Repeated Measurement General Linear Model

\begin{tabular}{lllll}
\hline Perhitungan & Value & F & Sig & Kesimpulan \\
\hline Hotelling's Trance & 22,293 & 66,880 & 0,000 & Sangat Signifikan \\
\hline
\end{tabular}

Berdasarkan hasil analisis Anava Repeated Measurement General Linear Model: Multivariate test diketahui bahwa nilai Hotelling's Trance sebesar 22,293 memiliki $F$ hitung sebesar 66,880 dan nilai $p=0,000$. Oleh karena nilai $p<$
0,05, maka terbukti secara statistik hasil kecemasan berbeda nyata, artinya antara nilai prates, pascates dan tindak lanjut terbukti saling berbeda secara signifikan pada taraf kepercayaan $95 \%$. 
Tabel 5. Anava Repeated Measurement Test of Within Subjects Effect dengan Menggunakan Skor Skala Kecemasan

\begin{tabular}{|c|c|c|c|c|}
\hline Perhitungan & $\begin{array}{l}\text { Type III Sum of } \\
\text { Square }\end{array}$ & $\mathrm{F}$ & Sig & Kesimpulan \\
\hline Pengukuran kecemasan & 75,433 & 61,638 & 0,00 & Signifikan \\
\hline Pengukuran & 91,878 & 75,075 & 0,00 & Signifikan \\
\hline Kecemasan"kelompok & & & & \\
\hline
\end{tabular}

Berdasarkan hasil uji beda meng- Pada bagian pengukuran kecemasan gunakan anava repeated measurement kelompok tampak bahwa $\mathrm{F}$ hitungnya diketahui bahwa pada pengukuran kece- sebesar 91,878 dan nilai $p=0,00$. Oleh masan memiliki $\mathrm{F}$ hitung sebesar 61,638 karena nilai $\mathrm{p}<0,05$, maka terbukti dan nilai $p=0,00$. Oleh karena nilai $p$ bahwa kelompok yang diberikan pe$<0,05$, maka terbukti secara statistik latihan atau kelompok yang tidak dibehasil skor kecemasan berbeda nyata. rikan pelatihan memberikan pengaruh Artinya, antara nilai prates, pascates, dan signifikan terhadap beda nilai pates, tindak lanjut dalam pengukuran berulang pascates dan tindak lanjut dalam terbukti saling berbeda secara signifikan. pengukuran berulang.

Tabel 6. Anava Repeated Measurement Test of Between Subject Effect dengan menggunakan skor kecemasan

\begin{tabular}{lllll}
\hline Perhitungan & $\begin{array}{l}\text { Type III Sum of } \\
\text { Square }\end{array}$ & F & Sig & Kesimpulan \\
& 36,817 & 3,098 & 0,122 & Tidak \\
\hline Kelompok & & & & Signifikan \\
& & &
\end{tabular}

Berdasarkan analisis Anava Re- hadap beda nilai saat prates, pascates dan peated Measurement, pada bagian tindak lanjut dalam pengukuran berulang kelompok tampak nilai $\mathrm{F}$ hitung 3,098 pada taraf kepercayaan $95 \%$. dan nilai $p=0,122$. Oleh karena nilai $p$ $>0,05$, maka kelompok tidak terbukti memberikan pengaruh signifikan ter- 


\section{PEMBAHASAN}

Penelitian ini bertujuan untuk mengetahui penurunan kecemasan pada lansia hipertensi yang diberikan pelatihan shalat khusyuk. Berdasarkan hasil penelitian dan analisis data yang telah dilakukan diketahui bahwa ada perbedaan tingkat skor kecemasan antara kelompok eksperimen yang diberikan pelatihan dengan kelompok kontrol yang tidak diberikan pelatihan. Perbedaan tingkat kecemasan kedua kelompok tersebut juga dapat dilihat dari grafik dan hasil data secara kualitatif yang menjelaskan kondisi subjek setelah mendapatkan pelatihan.

Hasil penelitian menunjukkan adanya penurunan kecemasan yang signifikan pada saat sebelum pelatihan dan sesudah pelatihan shalat khusyuk. Adanya penurunan skor kecemasan dari para subjek dalam mengikuti pelatihan tidak lepas dari pengaruh edukasi dan pelatihan shalat khusyuk yang disusun berdasarkan tahapan yang saling berkesinambungan, sehingga subjek bisa merasakan manfaat dari proses pelatihan yang dilaksanakan. Subjek merasakan perubahan positif setelah mengikuti kegiatan pelatihan ini. Subjek yang merupakan penderita hipertensi dapat merasakan manfaatnya langsung berupa berkurang- nya ketegangan, kekhawatiran, mudah gelisah, sesak nafas, gangguan tidur, sakit kepala, berkeringat panas/ dingin, mudah gugup, sulit konsentrasi, sakit perut, penglihatan kabur, serta tekanan darah cenderung tinggi, secara berangsurangsur mengalami penurunan yang dialami. Setelah menjalani proses pelatihan shalat khusyuk, secara berangsur-angsur mengalami penurunan terhadap keluhan pikiran, perasaan, dan perilaku yang mereka alami tersebut.

Hasil ini mendukung firman Allah swt dalam surat Ar-Rad ayat 28 yang berbunyi: (yaitu) orang-orang yang beriman dan hati mereka menjadi tenteram dengan mengingat Allah. Ingatlah, hanya dengan mengingati Allah-lah hati menjadi tenteram (QS. 13:28). Hasil penelitian ini juga mendukung pendapat dan pengalaman Purwanto (2014) yang menunjukkan bahwa pada saat shalat, yaitu ketika hati tersambung kepada Allah, ada proses yang meng-antarkan diri kepada ketenangan jiwa dan pikiran. Penelitian yang dilakukan Ari (2001) juga mendukung penelitian ini, yaitu shalat memiliki kemampuan untuk mengurangi kecemasan.

Secara keseluruhan pada penelitian ini, pada kelompok yang mendapat pelatihan berupa shalat khusyuk mengalami penurunan kecemasan bahkan 
setelah dua minggu setelah dilakukan pelatihan. Hal tersebut bisa dilihat dari perbedaan skor kecemasan antara kelompok yang mendapatkan pelatihan dengan kelompok yang tidak mendapatkan pelatihan saat melakukan pengukuran kecemasan di akhir penelitian dan saat tindak lanjut dua minggu setelah pelatihan. Kelompok yang mendapat pelatihan mengalami penurunan tingkat kecemasan dan kelompok yang tidak diberi pelatihan tidak mengalami penurunan. Hal ini sesuai dengan Ahmad (2008) yang mengungkapkan bahwa manfaat shalat dengan khusyuk adalah mendekatkan diri kepada Allah Swt, menjauhkan penyakit dari tubuh, membuat jiwa dan raga aktif, mendapatkan asupan gizi bagi ruh dan hati, meredamkan nafsu syahwat, menerangi hati, melapangkan dada, dan membuat jiwa bahagia. Najati (2005) mengatakan bahwa shalat secara khusyuk dengan niat menghadap dan berserah diri kepada Allah serta meninggalkan semua kesibukan di dunia, maka seseorang akan merasa tenang, tentram dan damai. Hasil penelitian ini juga sejalan dengan pendapat Wadji dan Rahmani (2009) bahwa dengan shalat maka jiwa menemukan kelapangan yang sempurna, jauh dari ketegangan dan tekanan, serta mengendalikan emosi.
Penurunan tingkat kecemasan antar subjek pada kelompok yang mendapatkan pelatihan berbeda-beda, ada beberapa subjek yang penurunannya masih berada pada tingkat sedang dan ada juga yang sampai kategori rendah. Hal ini dipengaruhi oleh motivasi subjek dalam mengikuti proses pelatihan yang berbeda-beda. Berdasarkan hasil observasi pada subjek, ada 4 subjek yang aktif, antusias, dan ada rasa ingin tahu dalam mengikuti tahapan pelatihan. Sementara seorang subjek, kurang terlibat aktif dalam proses pelatihan. Hal ini, didukung dengan sikap subjek yang pemalu dan sulit untuk melakukan proses pelatihan shalat khusyuk dikarenakan kakinya sedang sakit.

Motivasi merupakan dorongan psikologis yang mengarahkan seseorang kearah tujuan. Adanya motivasi dalam diri seseorang akan membuat keadaan dalam diri muncul, terarah dan cenderung mempertahankan perilaku. Begitu juga dengan subjek yang memiliki motivasi yang tinggi dalam mengikuti proses pelatihan, maka akan menunjukkan efek pelatihan yang baik. Sejalan dengan pendapat Purwanto (2014) bahwa shalat dibarengi dengan motivasi dari dalam adalah salah satu cara untuk menghilangkan beban dan hal ini terkait dengan cara bersyukur. Dengan ber- 
syukur dalam shalat, niscaya kebahagiaan hidup pun akan bertambah.

Sebuah penelitian tidak selamanya sempurna. Begitu pun halnya dengan penelitian ini. Penelitian ini memiliki beberapa kekurangan seperti (a) kendala bahasa dikarenakan co-pelatih kurang menguasai bahasa Jawa sehingga ada kesulitan untuk berkomunikasi dengan subjek sementara para subjek kurang mampu menyampaikan dengan menggunakan Bahasa Indonesia sehingga diperlukan penterjemah bahasa saat proses pelatihan. (b) gerakan lansia yang kurang sempurna dikarenakan kondisi fisik lansia yang kurang sehat dan sulit untuk melakukan gerakan shalat, seperti menekukkan kaki. (c) Lansia memiliki keterbatasan dalam gerakan dan bacaan shalat sehingga lansia berfokus dengan ketenangan hati saat melakukan latihan shalat khusyuk. (d) adanya perubahan rancangan penelitian atau modul penelitian dikarenakan untuk penyesuaian dengan kondisi lansia.

Evaluasi selanjutnya dalam penelitian ini juga dilakukan untuk mengetahui apakah materi yang disampaikan dalam pelatihan sudah cukup dipahami para subjek selama proses pelatihan berlangsung. Hasilnya berdasarkan pengakuan para subjek diketahui bahwa penyampaian materi dari pelatih shalat khusyuk sudah cukup jelas dan menyenangkan serta bahasa yang digunakan dalam penyampaian materi juga bersahabat dan diselingi candaan dengan para subjek, sehingga para subjek merasa lebih nyaman dalam mengikuti pelatihan.

Para subjek mengungkapkan bahwa mereka mendapatkan manfaat berupa berpikir positif dan nyaman saat menjalankan aktivitas kesehariannya. Subjek merasa dekat dengan Allah, sehingga dapat menerima keadaan yang dihadapi dalam kehidupan saat ini dan yang akan datang. Selain itu juga didukung dengan kekhusyukan hati atau fokus dengan apa yang dirasakan dan mengikuti setiap pelatihan shalat khusyuk hingga selesai. Hal ini cukup menjelaskan bahwa pelatihan ini membantu subjek penderita hipertensi dalam menurunkan kecemasan.

Berdasarkan hasil analisis menunjukkan bahwa hipotesis yang diajukan diterima, akan tetapi penelitian ini memiliki keterbatasan antara lain skala yang digunakan untuk mengungkap gangguan psikologis banyak yang sudah biasa dialami oleh lansia. Berdasarkan uraian di atas, maka peneliti ini masih banyak membutuhkan penyempurnaan jika ada peneliti yang tertarik untuk melakukan peneliti lanjutan. Kekurangan penelitian ini diharapkan dapat disempurnakan 


\section{SIMPULAN DAN SARAN}

\section{Simpulan}

Hasil penelitian ini menunjukkan bahwa pelatihan shalat khusyuk dapar mengurangi kecemasan pada lansia hipertensi. Kelompok yang mendapatkan pelatihan shalat khusyuk lebih rendah kecemasannya dibandingkan dengan kelompok yang tidak mendapatkan pelatihan shalat khusyuk.

\section{Saran}

Ada sejumlah saran yang dapat peneliti ajukan. Pertama: saran untuk peneliti berikutnya. Pelatihan shalat khusyuk terbukti mampu mengurangi kecemasan pada lansia hipertensi. Hasil ini bisa menjadi acuan bagi peneliti berikutnya untuk mengembangkan pelatihan shalat khusyuk dengan menggunakan teknik shalat yang lain. Jika peneliti berikutnya tertarik untuk meneruskan penelitian ini, peneliti menyarankan agar peneliti berikutnya memahami dan akan lebih baik lagi jika telah mengaplikasikan shalat khusyuk. Proses tersebut menjadi pintu untuk meyakinkan para subjek bahwa pelatihan shalat khusyuk mampu membuat seseorang merasa lebih tenang dan nyaman. Selain itu, peneliti berikutnya harus memperhatikan kondisi kesehatan subjek penelitian sehingga gerakan shalat sempurna dapat terlaksana hingga tercapainya ketenangan hati. Jika kondisi kesehatan lansia tidak memungkinkan untuk melakukan gerakan secara sempurna, peneliti berikutnya dapat menerapkan gerakan yang fleksibel dan berfokus pada ketenangan hati sehingga dapat dilakukan oleh subjek penelitian.

Kedua: saran untuk subjek penelitian. Subjek penelitian diharapkan untuk dapat melakukan gerakan yang sempurna ataupun gerakan yang fleksibel saat kondisi tidak memungkinkan untuk melakukan gerakan sempurna. Selain itu, agar subjek peneliti dapat menghadirkan hati atau khusyuk saat melakukan shalat agar tercapainya ketenangan hati.

\section{DAFTAR PUSTAKA}

Adi, A. W. (2002). Psikologi transpersonal, makalah dalam seminar Psikologi Islam. Solo: Fakultas Psikologi UMS.
Ahmad, B. S. (2008). Misteri pengobatan dalam shalat: Menguap rahasia pengobatan dan kesehatan dalam ibadah shalat. Jakarta: Mirqad Media Grafika. 
Ancok, D. \& Suroso, F.N. (2011). Psikologi islami: Solusi islam atas problem-problem psikologi. Yogyakarta: Pustaka Pelajar.

Ashy, M. A. (1999). Health and illness from an Islamic perspective. Journal of Religion and Health. 38, 241-257.

Ayers, C. R,Sorell, J. T, Throp, S. R, Wetherell, J. L. (2007). Evidancebased psychological treatments for late life anxiety. Psychology and Aging. 22 (1), 8-17.

Beck, A. T. (1989). Cognitive therapy and the emotional disorders. England: Penguins Books Ltd.

Dinkes DIY. (2013). Waspadai hipertensi kendalikan hipertensi. Yogyakarta: Dinkes DIY.

Irawati, D., Subandi, \& Kumolohadi, R. (2011). Pelatihan kognitif perilaku religius untuk menurunkan kecemasan terhadap kematian pada penderita HIV/AIDS. Jurnal Intervensi Psikologi. 3 (2), 175.

Isfandari, S. (1999). Gejala psikologis pada lanjut usia di Depok dan
Senen. Buletin Penelitian Kesehatan. 26, (1), 26-35.

Kabo, P. (2010). Menggunakan obat-obat kardiovaskular secara rasional. Jakarta: Balai Penerbit Fakultas Kedokteran UI.

Kementrian Kesehatan RI. (2013). Diunduh pada tanggal 19 Mei 2015 http://www.depkes.go.id/ article/view/201405300004/pende katan-siklus-hidup-dalam-pelayan an-kesehatan-lanjut-usia.html.

Najati, M. U. (2005). Psikologi nabi. Bandung: Pustaka Hidayah.

Nashori, F. (1997) Psikologi Islami: Agenda Menuju Aksi. Yogyakarta: Pustaka Pelajar

Nashori, F. (2007). Manusia sebagai homo religious. Jurnal Psikologika, $12(2), 3$.

Nugroho, W. (2000). Keperawatan geriatrik. Edisi 2. Jakarta: EGC.

Papalia, D.E., Olds, S.W., \& Feldman, R.D. 2008. Human Development. $9^{\text {th }}$ ed. New York: McGraw-Hill Co. 
Puwanto, S. (2014). Catatan harian trainer shalat khusyuk. Solo: Romiz Aisy.

Seniati, L., Yulianto, A. \& Setiadi, B. N. (2005). Psikologi eksperimen. Jakarta: Indek

Sharp, S. (2010). How does prayer help manage emoticons? Social Psychology Quarterly. 73, 417-437

Syed, I. B. (2003). Spiritual medicine in the history of islamic medicine.
Journal of the International Society for the History of Islamic Medicine (ISHIM). 2 (4), 45-49.

Tim Penerjemah. (2002). Al-Qur'an dan terjemahannya. Jakarta: Kementrian Agama Republik Indonesia.

Uyun, Q. \& Rumiani. (2012). Sabar dan shalat sebagai model untuk meningkatkan resiliensi di Daerah Bencana Yogyakarta. Jurnal Intervensi Psikologi. 4 (2), 253267. 